\title{
TINJAUAN HUKUM PRAKTIK BISNIS BERKEADILAN MELALUI PENINGKATAN AKSESIBILITAS KONSUMEN
}

\author{
Abi Jumroh Harahap \\ Fakultas Hukum Universitas Medan Area \\ Email: abi.jumroh@yahoo.com
}

\begin{abstract}
In the mid of free trade era, both in domestic and international level, consumer protection issues has become more relevan to be examined. One of the important aspect in the field of consumer protection that should be strengthened is consumer's access to justice. The complexity of global trade marked by unfair commercial practices have often negative impacts for consumer; consumer rights often be ignored and violated by business people. Therefore government must be able to ensure the existence of consumer's access to justice through the rule making, policy, and the new legal institutionalization in order to create fair business environment.
\end{abstract}

\section{Kata Kunci: Konsumen, Perlindungan Konsumen, Akses Keadilan.}

\section{A. Latar Belakang}

Isu perlindungan konsumen terus menjadi perhatian banyak pihak di berbagai negara, tidak terkecuali di Indonesia. Hal tersebut akibat meningkatnya perdagangan global (bebas) yang dampaknya di tingkat konsumen makin dirasakan masyarakat. Seiring dengan pertumbuhan dunia perdagangan dan industri itu, posisi konsumen (khususnya di negara berkembang) kian terpuruk karena lemahnya daya tawar, tingkat pendidikan dan ketidaktahuannya akan berbagai produk barang dan jasa yang beredar di pasaran. Oleh karena itu, pertumbuhan dunia perdagangan dan industri di satu sisi, sedangkan di sisi lain senantiasa menuntut berbagai upaya yang sungguh-sungguh dalam melindungi kepentingan konsumen, sehingga tercipta perdagangan atau perniagaan yang adil bagi konsumen.

Ketidaktahuan konsumen (consumer ignorance) sesungguhnya merupakan realitas yang harus dihadapi konsumen (siapapun konsumen itu, baik kaya atau miskin, di pedesaan maupun di perkotaan) ketika berhadapan dengan setiap 
produk barang dan atau jasa yang beredar di pasar. Metode promosi yang cenderung menyesatkan dan penggunaan teknologi tinggi dalam proses produksi maupun distribusi dan pemasarannya, makin memposisikan konsumen tidak terinformasi dan cenderung untuk menerima apa adanya karena ketidaktahuannya.

Hampir semua informasi tentang produk barang dan atau jasa yang mengiringi peredarannya, seolah-olah mesti diterima konsumen sebagai sesuatu yang "given", bahkan ketika barang dan atau jasa itu tidak sesuai dengan apa yang seharusnya ia terima, maka seiring dengan perkembangan dunia industri dan perdagangan yang makin kompleks, makin lemah pula posisi konsumen. Konsumen kemudian tidak lagi tampak sebagai subjek (pelaku) ekonomi, melainkan cenderung menjadi objek bagi kalangan pelaku usaha untuk meraih keuntungan. Dalam kondisi seperti ini, dapat dipastikan bahwa kepentingan dan hak-hak konsumen akan diabaikan. Dengan kata lain, dari sisi perlindungan konsumen, perniagaan berkeadilan belum terwujud di Indonesia.

Perlindungan konsumen sebenarnya mencakup berbagai topik, termasuk tidak terbatas pada tanggungjawab produk (product liability), hak privasi (privacy rights), praktik bisnis yang tidak adil (unfair business practices), penipuan (fraud), kekeliruan (misrepresentation), dan interaksi konsumen/bisnis lainnya. Konsep perniagaan yang berkeadilan (fair business) di sini mensyaratkan antara lain, suatu situasi dimana pelaku usaha senantiasa mempraktikkan dan mempromosikan pemberian informasi yang akurat bagi konsumen dalam setiap promosi dan peredaran barang dan/atau jasa (sebelum konsumen membeli produk barang dan jasa) di antara tujuan-tujuan yang lain, termasuk di dalamnya menyangkut keamanan produk.

Apa yang dikatakan oleh dunia usaha atas produk barang dan/atau jasa di dalam promosi atau iklan adalah suatu hal yang penting bagi perlindungan konsumen. Mempertimbangkan bahwa perniagaan yang adil tidak akan terwujud dengan sendirinya tanpa intervensi pemerintah, peran dunia usaha, dan konsumen, maka salah satu aspek penting yang harus dikembangkan dalam upaya mewujudkan perlindungan konsumen adalah peningkatan akses keadilan konsumen. Di tengah masih rendahnya tingkat kesadaran konsumen, berbagai regulasi serta 
sarana dan prasarana yang memperluas akses keadilan konsumen perlu terus didorong untuk diwujudkan.

Pengertian akses menuju keadilan adalah kesempatan atau kemampuan setiap warga negara tanpa membedakan latar belakangnya (ras, agama, keturunan, pendidikan, atau tempat lahirnya) untuk memperoleh keadilan (melalui lembaga peradilan). Termasuk juga akses bagi masyarakat khususnya bagi kelompok miskin, buta hukum, dan tidak berpendidikan terhadap mekanisme yang adil dan akuntabel (bertanggungjawab) untuk memperoleh keadilan dalam sistem hukum positif melalui lembaga peradilan (J. Djohansjah, 2010: 57). Takdir Rahmadi (2011: 34), berpandangan bahwa akses keadilan menyangkut ketersediaan asas hukum, norma-norma hukum materiil dan formil dalam sistem hukum Indonesia serta kebijakan/program lembaga peradilan yang dapat memfasilitasi ataupun dapat dijadikan dasar oleh para pihak berperkara maupun masyarakat pada umumnya untuk mewujudkan keadilan.

Dalam konteks perlindungan konsumen, dinyatakan bahwa akses keadilan konsumen meliputi: kemampuan untuk membawa klaim dan berhasil memperoleh kompensasi, kemampuan untuk mempertahankan klaim yang tidak cukup bukti, biaya proporsional, prosedur yang efektif dan sederhana; proses cepat dari awal hingga kesimpulan, dan penegakan hukum yang efektif dari suatu keputusan. Lebih lanjut menurutnya, skema Small Claims Court dan Ombudsman yang bisa mewujudkan akses perlindungan konsumen tersebut, bukan pengadilan (Michell Lyttle, 2009: 7), tetapi di Indonesia, mekanisme Small Claims Court belum diperkenalkan, sedangkan Ombudsman sudah diinisiasi sejak lahirnya Komisi Ombudsman Nasional (KON) melalui Keputusan Presiden Nomor 44 tahun 2000 dan kemudian diperkuat melalui Undang-undang Nomor 37 Tahun 2008 tentang Ombudsman Republik Indonesia, termasuk keberadaan Ombudsman Daerah di beberapa wilayah di Indonesia.

Akses keadilan konsumen melalui skema Ombudsman (sektor bisnis privat) juga perlu didorong dan dikembangkan di Indonesia karena dunia perdagangan dan industri yang terus tumbuh dan berkembang makin kompleks yang akhir-akhir ini melahirkan ketidakadilan sosial dan ekonomi bagi konsumen. 
Hubungan interdependensi yang ada antara pelaku usaha dan konsumen dalam perdagangan tradisional, praktis bergeser ke arah dependensi konsumen terhadap dunia usaha.

Akibatnya posisi tawar konsumen menjadi lemah, apalagi dengan adanya dominasi kekuatan pasar (yang antara lain ditandai dengan pertumbuhan konglomerasi dan Multi National Corporation (MNC), menjadikan nasib konsumen makin terpuruk. Keterpurukan nasib konsumen makin lengkap dengan maraknya praktik-praktik usaha yang tidak sehat/curang (unfair trade practices) dalam berbagai modus dan bentuknya di berbagai sektor atau tahap perniagaan. Berbagai kecurangan bahkan kejahatan pelaku usaha sudah dimulai dan dapat terjadi sejak tahap proses produksi, pemasaran, distribusi, sampai dengan tahap konsumsi. Seringkali praktik usaha semacam ini dilakukan dengan justifikasi untuk bertahan dalam memenangkan persaingan usaha atau guna melipatgandakan keuntungan. Selain itu, lemahnya kebijakan dan pengawasan oleh instansi pemerintah atau penegak hukum terkait, berdampak pada tumbuhnya praktik usaha yang unfair tersebut yang akhirnya (pasti) melahirkan kerugian di tingkat konsumen.

\section{B. Perumusan Masalah}

Sehubungan dengan latar belakang yang diuraikan di atas, maka rumusan masalahan dalam artikel ini adalah untuk menganalisis hal-hal berikut:

1. Mengapa akses keadilan konsumen sangat diperlukan dalam mewujudkan perniagaan yang adil?

2. Apa saja prinsip-prinsip yang perlu dikembangkan dalam peningkatan akses keadilan konsumen?

\section{Metode Penelitian}

Penelitian ini mengkaji pokok permasalahan sesuai dengan ruang lingkup dan identifikasi masalah dengan jenis penelitian yuridis normatif. Dalam penelitian ini penulis melakukan penelitian asas-asas hukum yang bertitik tolak dari bidang-bidang tata hukum tertentu, dengan cara mengadakan identifikasi 
terlebih dahulu terhadap kaidah-kaidah hukum yang telah dirumuskan di dalam perundang-undangan.

Sifat penelitian ini adalah deskriptif, yang bertujuan untuk memberikan gambaran tentang gejala-gejala sosial yang terkait dengan masalah akses keadilan konsumen sangat diperlukan dalam mewujudkan perniagaan yang adil serta prinsip-prinsip yang perlu dikembangkan. Sumber data penelitian berupa bahan hukum primer, bahan hukum sekunder dan bahan hukum tersier. Metode pengumpulan data dilakukan menggunakan teknik studi dokumen, yang dianalisis dengan menggunakan teknik analisis kualitatif.

\section{Hasil Penelitian dan Analisis}

\section{Akses keadilan konsumen dalam mewujudkan perniagaan yang adil}

John Rawls (1971: 12) dalam bukunya "A Theory of Justice” menyatakan bahwa keadilan adalah kebajikan pertama lembaga-lembaga sosial, sebagai kebenaran sistem berpikir. Sebuah teori meskipun elegan dan ekonomis, harus ditolak atau direvisi jika itu tidak benar, juga hukum dan institusi, tidak peduli seberapa efisien dan diatur dengan baik, harus direformasi atau dihapuskan jika hal itu tidak adil. Setiap orang memiliki sesuatu yang tidak dapat diganggu gugat yang didasarkan pada keadilan, bahkan kesejahteraan masyarakat secara keseluruhan tidak dapat menggantinya. Untuk alasan ini, keadilan menolak bahwa hilangnya kebebasan untuk beberapa hal dibenarkan oleh kebaikan yang lebih besar dimiliki yang oleh orang lain.

Kebebasan kewarganegaraan yang sama dalam masyarakat yang adil harus tetap, hak-hak yang dijamin oleh keadilan tidak tunduk pada tawar-menawar politik atau kalkulus kepentingan sosial. Satu-satunya hal yang memungkinkan untuk menyetujui dalam teori yang salah adalah minimnya hal yang lebih baik analog dengan sebuah ketidakadilan ditoleransi hanya dapat diperlukan untuk menghindari lebih besar ketidakadilan. Menjadi kebajikan pertama kegiatan manusia, kebenaran dan keadilan tanpa kompromi. Proposisi ini tampaknya untuk mengekspresikan keyakinan intuitif tentang keutamaan keadilan. 
Rawls (1971:13) juga menyatakan perlunya mempertimbangkan peran prinsip-prinsip keadilan karena konflik kepentingan selalu terjadi di dalam masyarakat. Menurutnya, konflik kepentingan terjadi karena orang tidak peduli bagaimana manfaat besar yang dihasilkan oleh kerjasama mereka didistribusikan, mereka lebih mengejar tujuan mereka masing-masing. Seperangkat prinsip-prinsip diperlukan untuk memilih di antara berbagai pengaturan sosial yang menentukan pembagian keuntungan ini.

Prinsip-prinsip tersebut adalah prinsip-prinsip keadilan sosial yang menyediakan cara menetapkan hak dan kewajiban dalam institusi dasar masyarakat dan yang menentukan distribusi yang tepat manfaat dan beban kerjasama sosial. Dapat dikatakan bahwa sebuah masyarakat tertata dengan baik jika tidak hanya dirancang untuk memajukan kebaikan anggotanya, tetapi juga efektif diatur oleh konsepsi keadilan masyarakat. Artinya, itu adalah masyarakat dimana (a) setiap orang menerima dan mengetahui bahwa orang lain menerima sama prinsip-prinsip keadilan, dan (b) lembaga-lembaga sosial dasar umumnya memenuhi dan umumnya dikenal untuk memenuhi prinsip-prinsip ini.

Pengembangan kelembagaan yang dimaksudkan untuk mewujudkan keadilan sosial harus terus menerus dikembangkan, tetapi Rawls mengingatkan bahwa beberapa tindakan kesepakatan dalam konsepsi keadilan, bagaimanapun, bukan satu-satunya prasyarat untuk sebuah komunitas manusia yang layak (viable). Ada masalah sosial mendasar lainnya, khususnya koordinasi, efisiensi, dan stabilitas. Dengan demikian menurutnya, rencana individu perlu dicocokkan bersama-sama sehingga kegiatan mereka cocok satu dengan lainnya dan semuanya dapat dilakukan. Selain itu, pelaksanaan rencana ini harus mengarah pada pencapaian tujuan sosial dengan cara yang efisien dan konsisten dengan keadilan dan akhirnya skema kerjasama sosial harus stabil, hal itu harus kurang lebih terus dipatuhi dan aturan dasar yang bukan ruang untuk dikritisi dan ditanggapi dan ketika pelanggaran terjadi, kekuatan stabilisasi harus ada untuk mencegah pelanggaran lebih lanjut dan untuk memulihkan tatanan yang ada.

Berdasarkan pada pandangan Rawls tersebut di atas, maka masalah akses keadilan menjadi relevan untuk terus menerus ditingkatkan. Terdapat hubungan 
yang sangat erat antara stabilitas, keadilan dan kesejahteraan. Diyakini bahwa perbaikan aspek hukum dan keadilan akan mendukung pencapaian kesejahteraan dan stabilitas, tidak terkecuali dalam dunia perdagangan/perniagaan.

Akses hukum dan keadilan dipahami sebagai akses bagi masyarakat, khususnya bagi kelompok miskin terhadap mekanisme yang adil, efektif dan akuntabel untuk melindungi hak, menghadapi posisi dominan, menghindari penyalahgunaan kekuasaan, dan penyelesaian konflik. Termasuk di dalamnya adalah kemampuan masyarakat untuk memperoleh dan mendapatkan penyelesaian melalui mekanisme formal dan informal dalam sistem hukum, serta kemampuan untuk memperoleh dan terlibat dalam proses pembuatan dan penerapan dan pelembagaan hukum (World Bank, 2016: 5).

Dilihat dari dampaknya, peningkatan akses keadilan juga sesuai dengan Teori Utilitarian. Utilitarianisme adalah suatu teori dari segi etika normatif yang menyatakan bahwa suatu tindakan yang patut adalah yang memaksimalkan penggunaan (utility), biasanya didefinisikan sebagai memaksimalkan kebahagiaan dan mengurangi penderitaan. Beberapa pokok ajarannya adalah: (a) seseorang hendaknya bertindak sedemikian rupa, sehingga memajukan kebahagiaan (kesenangan) terbesar dari sejumlah besar orang; (b) tindakan secara moral dapat dibenarkan jika ia menghasilkan lebih banyak kebaikan daripada kejahatan, dibandingkan tindakan yang mungkin diambil dalam situasi dan kondisi yang sama, secara umum harkat atau nilai moral tindakan dinilai menurut kebaikan dan keburukan akibatnya; (c) ajaran bahwa prinsip kegunaan terbesar hendaknya menjadi kriteria dalam perkara etis. Kriteria itu harus diterapkan pada konsekuensi-konsekuensi yang timbul dari keputusan-keputusan etis (Editor Wikipedia, 2016: 2).

Masalah akses keadilan di Indonesia mengemuka terutama pasca reformasi tahun 1998 karena terjadinya berbagai ketidakadilan sosial seperti kemiskinan, ketidakadilan gender, korupsi, hak-hak atas tanah dan perumahan yang terbatas, lemahnya kedudukan buruh, minimnya pendapatan, ketidakadilan distribusi kesejahteraan, keterbatasan akses terhadap pendidikan pada umumnya dan pendidikan hukum, penurunan kualitas lingkungan, masalah-masalah kesehatan, 
diskriminasi minoritas, dan lain-lain. Dalam konteks hukum adanya keterbatasan dan ketidaksamaan akses terhadap informasi hukum, proses pembentukan peraturan dan lembaga-lembaga hukum, birokrasi, peradilan, dan lembagalembaga penyelesaian sengketa lainnya, juga menunjukkan ketidakadilan sosial. Dengan kondisi seperti itu, sebagai bagian dari reformasi hukum, lahirlah strategi nasional untuk akses terhadap keadilan (Jacqueline Vel, 2011: 8).

Mengkonsolidasikan kebijakan pemerintah Indonesia mengenai akses terhadap hukum dan keadilan menjadi strategi nasional yang jelas, koheren dan diikuti dengan rencana kerja diharapkan akan (a) membangun lembaga hukum yang lebih kuat; (b) menanggulangi kemiskinan dan memberdayakan masyarakat agar mampu mengeloa kehidupannya sendiri; serta, pada gilirannya, (c) memperkuat kemanan nasional. Sebuah strategi nasional akses terhadap hukum dan keadilan akan melengkapi berbagai upaya reformasi lembaga hukum yang sedang berjalan.

Penguatan terhadap sektor keadilan formal merupakan aspek penting dalam mendorong akses hukum dan keadilan, berbagai upaya tersebut belum dapat optimal jika masyarakat sendiri belum memiliki kesadaran atas hak-hak mereka, atau mengakses lembaga-lembaga hukum akibat hambatan geografis, finansial atau pengetahuan. Penguatan akses keadilan juga harus mempertimbangkan fakta bahwa proses penyelesaian sengketa di masyarakat pada umumnya diselesaikan melalui mekanisme informal.

Reformasi keadilan yang komprehensif mengandaikan adanya dua strategi yang dijalankan bersamaan yang menghubungkan antara reformasi kelembagaan dari tingkat pusat (supply) dan aspirasi dari masyarakat untuk mendapat akses dan pelayanan hukum yang lebih baik (demand). Strategi tersebut diyakini dapat membawa keadilan lebih dekat bagi masyarakat. Pendekatan ini akan menjawab persoalan rendahnya kepercayaan dan bias hukum sebagaimana persepsi banyak orang, terutama oleh masyarakat miskin, saat berupaya mencari keadilan (World Bank, 2011: 9). 
Terdapat tiga dasar pemikiran utama untuk mengkonsolidasikan kebijakan pemerintah dan peraturan hukum dalam sebuah strategi nasional yang jelas dan koheren, yaitu:

a. Reformasi kelembagaan, yang seharusnya responsif terhadap kebutuhan masyarakat, sebuah strategi nasional akan menghubung-kan permintaan masyarakat akan pelayanan hukum yang lebih baik guna menjawab kebutuhan segenap masyarakat Indonesia, mencakup lembaga keadilan formal dan informal.

b. Keadilan dan kemiskinan, karena melalui peningkatan akses hukum dan keadilan akan melengkapi upaya pemerintah untuk menanggulangi kemiskinan dan pemberdayaan masyarakat.

c. Justice and security, karena melalui peningkatan efektifitas dan kepercayaan terhadap sistem hukum yang pada giliranya dapat mengurangi konflik dan memperbaiki jaminan keamanan masyarakat.

Selain itu, dibutuhkan pula akses terhadap lembaga-lembaga penyelesaian sengketa yang tepat yang mempunyai dimensi:

a. Akses fisik, yang merujuk pada kepastian bahwa lembaga hukum dekat dengan masyarakat pemanfaat dan menyediakan pelayanan yang ramah serta mudah dimengerti. Hal ini merupakan tantangan utama mengingat konteks wilayah kepulauan di Indonesia. Beberapa inisiatif seperti mengurangi jadwal persidangan atau mengenalkan pengadilan berjalan bisa jadi merupakah upaya untuk mengatasi masalah geografis.

b. Akses pembiayaan, bahwa biaya untuk mengakses lembaga hukum baik biaya langsung (filing fee) tidak langsung (transportasi) atau ilegal (suap/uang pelicin) merupakan hambatan besar bagi kelompok miskin untuk dapat mengakses sistem hukum.

c. Pelayanan hukum yang baik, bahwa kelompok miskin dan marginal harus diperlakukan dengan baik ketika mereka memutuskan untuk memakai lembaga formal. Melakukan survey publik mungkin dapat membantu peningkatan pelayanan masyarakat. 
d. Akses terhadap mekanisme penyelesaian sengketa alternatif, bahwa sebagian besar masyarakat menyelesaikan sengketa melalui mediasi dan arbritasi melalui sistem informal yang ada di tingkat desa (kepala desa, tokoh agama, lembaga adat).

Mekanisme informal secara fisik lebih mudah diakses dan cenderung disukai, tetapi seringkali mencerminkan ketidakseimbangan posisi tawar yang ada di masyarakat yang berakibat pada dikompromikannya kepentingan kelompok miskin, perempuan atau etnis minoritas. Dalam strategi nasional akses hukum dan keadilan seharusnya ditekankan penguatan kualitas dan keterbukaan dalam lembaga atau pelaku penyelesaian sengketa alternatif. Maurits Barendrecht (2009:32), menunjuk pandangan Cappelletti dan Garth serta Parker, menyatakan bahwa masalah akses keadilan berkaitan dengan bagaimana seseorang sesungguhnya menerima penyelesaian yang tepat dan adil atas konflik yang dihadapi, akses keadilan pada umumnya dikaji dari perspektif sosiolog, deskriptif dan tanpa suatu pandangan teoritis yang "mutual".

Secara tidak langsung istilah akses keadilan adalah suatu sudut pandang keadilan sebagai suatu bentuk akses masyarakat terhadap urusan organisasi advokat, pengadilan, dan legislasi. Banyak kajian mendeskripsikan bagaimana kesenjangan akses masyarakat, karena mereka menghadapi hambatan-hambatan keadilan. Studi tentang akses keadilan mendorong pembaharuan yang memungkinkan peningkatan akses terhadap keadilan. Literatur membedakan 5 (lima) hal yang mempengaruhi reformasi akses terhadap keadilan, yakni: (a) pemberian bantuan hukum; (b) litigasi kepentingan publik; (c) penyelesaian sengketa alternatif; (d) membuka pasar untuk layanan hukum (opening up the market for legal services); dan (e) aturan terhadap profesi hukum yang lebih baik.

Maurits Barendrecht (2016: 23), juga menyatakan bahwa akses keadilan adalah sebuah konsep yang luas. Ini menunjuk pada cara atau metode dimana seseorang dapat memperoleh informasi dan layanan hukum dan untuk menyelesaikan sengketa. Akses keadilan juga meliputi akses terhadap suatu prosedur di pengadilan, untuk mendapatkan bantuan hukum dan mekanisme ekstra legal (extra legal mechanisms) guna penyelesaian konflik. Seringkali, akses 
keadilan juga dilihat sebagai sesuatu yang problematik: prosedur yang melindungi hak-hak tertentu yang hilang (do not exist) atau tidak dapat diakses oleh seseorang karena keterbatasan sumberdaya.

Berdasarkan pada konsep akses keadilan di atas, maka dapat dikatakan bahwa perwujudan akses keadilan konsumen dalam konteks praktik perniagaan atau perdagangan nyata dibutuhkan di tengah praktik-praktik bisnis yang unfair dan lemahnya daya tawar konsumen dihadapan pelaku usaha. Akses keadilan konsumen ini diharapkan dapat meningkatkan posisi tawar konsumen sekaligus melindungi hak konsumen di tengah dominasi pelaku usaha dalam penyediaan dan peredaran produk barang dan/atau jasa.

\section{Prinsip-prinsip peningkatan akses keadilan konsumen}

Masalah perlindungan konsumen sebagai isu universal yang telah dituangkan ke dalam United Nations Guidelines for Consumer Protection (UNGCP) tidak hanya dimaksudkan untuk mendorong efisiensi ekonomi saja melainkan juga berkaitan dengan masalah keadilan sosial dan HAM. Terkait dengan hal ini David Harland (1997: 14) menyatakan bahwa:

Consumer protection is thus seen as not concerned solely with promoting economic efficiency (though this is an important aspect of it), but as ultimately concerned with issues of social justice and human rights. Under the heading "General Prinsiples", government are urged to develop, strengthen, or maintain a strong consumer protection policy...."

Dokumen UNGCP memulai dengan pengakuan bahwa konsumen sering menghadapi ketidakseimbangan ekonomi, tingkat pendidikan dan daya tawar. Selanjutnya ditegaskan bahwa konsumen seharusnya mempunyai hak untuk mendorong keadilan, pemerataan, dan pembangunan sosial, serta ekonomi berkelanjutan. Fungsi utama UNGCP ini adalah membantu negara-negara anggota PBB dalam pemberian kerangka terhadap kebijakan konsumen agar dapat dikembangkan dan dievaluasi. Pedoman ini juga mengakui bahwa, meskipun masalah mendasar dan prinsip-prinsip kebijakan konsumen adalah sama dimana pun, tidak ada satu solusi yang akan mempunyai validitas universal. Artinya masing-masing negara diminta untuk menetapkan prioritas mereka masing-masing 
karena peran yang tepat dari pemerintah suatu negara dalam mengimplementasikan kebijakan perlindungan konsumen juga dapat berbeda satu terhadap yang lain.

Perlu adanya langkah komprehensif yang tepat antara, di satu sisi, pengaturan hukum positif, dan di sisi lain, perlunya tindakan pemerintah dalam mengembangkan seluruh tujuan kebijakan dan mendorong serta memfasilitasi tindakan sukarela dari institusi bisnis dan organisasi konsumen. Hal terakhir inilah yang semestinya menjadi titik tolak perlunya pemerintah mendorong lahirnya mekanisme penyelesaian sengketa konsumen yang efektif, baik di tingkat internal organisasi bisnis yang bersifat sektoral maupun lintas sektor, atau lembaga penyelesaian sengketa yang independen seperti Ombudsman. Dalam hal ini, UNGCP dalam salah satu butir tujuan dari pedoman ini menyatakan bahwa negara anggota PBB mesti mengambil langkah-langkah atau membentuk mekanisme yang memungkinkan konsumen untuk memperoleh ganti rugi yang efektif (effective consumer redress).

Pada umumnya, konsumen menghadapi permasalahan akses keadilan manakala dirinya dirugikan oleh pelaku usaha. Sebagian besar di antaranya bahkan cenderung bersikap pasrah/menerima peristiwa yang menimpanya dan tidak mengambil langkah apapun (Nicole L'Heureux, 1992: 54). Andai kata mereka berjuang untuk mendapatkan hak-haknya pun, harus berjuang keras karena rendahnya sikap bertanggung jawab pelaku usaha dalam memberikan ganti kerugian. Lemahnya daya tawar konsumen di hadapan pelaku usaha serta lemahnya pengetahuan konsumen atas produk yang dikonsumsi, makin menyulitkan posisi konsumen dalam memperoleh hak-haknya. Mengenai sikap konsumen ini Nicole L'Heureux (1992:52), menyatakan ada 3 (tiga) persoalan yang dihadapi konsumen, yaitu:

a. tidak adanya kesadaran konsumen bahwa mereka mempunyai hak (hukum) yang dapat dimanfaatkan;

b. banyak konsumen tidak tahu bagaimana merumuskan tuntutan mereka;

c. keengganan mereka untuk membawanya ke pengadilan

Apabila konsumen hendak meminta bantuan hukum dari seorang advokat atau pengacara, mereka cenderung membatalkannya, karena biaya yang tidak 
murah harus dikeluarkan untuk membayar jasa hukum itu. Bahkan di Amerika Serikat sekalipun, pemberian akses keadilan konsumen sebagian besar terkendala oleh tingginya biaya jasa pengacara. Belum ada satu solusi yang menjawab persoalan tersebut, dan oleh sebab itu berbagai pendekatan yang mengarah kepada peningkatan akses keadilan konsumen harus dicoba.

Keberhasilan dan kegagalannya dapat lebih dipertimbangkan dari faktorfaktor politis dan struktural, ketimbang menyangkut langkah-langkah hukum substantif. Menurut Peter B. Maggs (1990: 36), dikatakan bahwa ada 9 (sembilan) pendekatan yang dapat dilakukan, meliputi: (a) pengurangan biaya pengacara dengan meningkatkan persaingan dalam pemberian jasa bantuan hukum; (b) menambah nilai jumlah ganti kerugian; (c) biaya yang disatukan (contingent fees); (d) membagi beaya pengacara melalui class action; (e) pemberian bantuan hukum pada konsumen tidak mampu oleh badan pemerintah; (f) pemberian jasa hukum bagi masyarakat pada umumnya oleh badan pemerintah; (g) menyederhanakan prosedur guna mengurangi kebutuhan jasa pengacara; (h) arbitrase; dan (i) mediasi.

Persoalan keengganan konsumen yang dirugikan untuk mengambil langkah hukum ke pengadilan, juga dinyatakan oleh Leigh Gibson (1992: 8), yang berpendapat bahwa: "consumers are clearly reluctant to take legal action in the courts, given the uncertainty of the outcome and the risk that the costs may be disproporsionate to the value of the claim". Oleh karena itu, dalam konteks perlindungan konsumen, prinsip-prinsip akses terhadap keadilan di atas tetap relevan karena pada dasarnya konsumen adalah subyek hukum yang lemah dan belum tersedianya akses terhadap keadilan konsumen yang efektif. Sehubungan hal ini, Michell Lyttle (2009: 7), menyatakan bahwa akses keadilan konsumen meliputi kemampuan untuk membawa klaim dan berhasil memperoleh kompensasi, kemampuan untuk mempertahankan klaim yang tidak cukup bukti, biaya proporsional, prosedur yang efektif dan sederhana, proses cepat dari awal hingga kesimpulan, dan penegakan hukum yang efektif dari suatu keputusan. Skema Small Claims Court dan Ombudsman yang dapat mewujudkan akses perlindungan konsumen tersebut, bukan pengadilan. 
Pendapat yang sama juga diungkapkan oleh Gralf-Peter Calliess (2006: 23), bahwa akses terhadap keadilan menyangkut setiap orang yang terlibat dalam sengketa berhak memperoleh mekanisme ganti rugi yang mudah diakses yang menyediakan penyelesaian sengketa dengan tepat waktu dan pemulihan yang efektif dengan biaya yang wajar.

Peningkatan akses keadilan konsumen dalam konteks perlindungan konsumen harus ditingkatkan dan dikembangkan melalui berbagai cara; sebagaimana dinyatakan oleh Iain Ramsay (2006: 3), yang berpendapat bahwa:

The issue of access to justice has been an important theme in consumer protection. Effective redress institutions may further the objectives of compensation, dispute settlement, behavior modification, and norm development, as well as providing confidence to consumers and business in a market. There has been continuing experimentation with a variety of institutions.

Pemerintah juga harus mendorong semua pelaku bisnis untuk menyelesaikan sengketa konsumen secara adil, cepat, dan dengan cara informal, serta membentuk mekanisme fakultatif, termasuk layanan informasi dan prosedur penyampaian keluhan secara informal, yang dapat membantu konsumen. Selain itu, informasi tentang kemungkinan memperoleh ganti rugi dan prosedur penyelesaian sengketa lainnya harus dibuat mudah diakses konsumen.

Mengapa mekanisme pemberian ganti rugi yang efektif bagi konsumen begitu penting? Mengenai hal ini penulis berpendapat bahwa persoalan mekanisme pemberian ganti rugi dapat dijelaskan dengan mengkaji lebih lanjut tentang karakteristik sengketa konsumen (consumer disputes) itu sendiri, yaitu:

a. Sengketa konsumen lahir dari tidak adanya keseimbangan kedudukan antara pihak pelaku usaha dan konsumen (J. Widijantoro, 2004: 10). Ketidakseimbangan kedudukan inilah yang seringkali menyulitkan konsumen untuk berjuang sendiri dalam menyelesaikan sengketa yang dihadapinya. Betul bahwa mereka sekarang secara yuridis dijamin hak-haknya, namun tetapi yang dapat menjamin bahwa hak-haknya tersebut akan dengan mudah diperolehnya? Bahkan The Australian Government Commission of Inquiry into Poverty menemukan bahwa di Australia masih banyak konsumen yang tidak menemukan petunjuk hukum (legal advice) ataupun tidak melakukan tindakan 
(hukum) apapun (ketika dirugikan), sementara mereka mengetahui apa yang menjadi hak-haknya sebagai konsumen. Penelitian Cass and Sackville membuktikan bahwa 15 dari 28 orang responden masuk kategori konsumen seperti tersebut di atas (John Goldring, 1998: 23).

Fakta ini juga didukung oleh fakta lain yang menunjukkan tingkat pengetahuan konsumen terhadap UU Perlindungan Konsumen (UUPK). CUTS International dan Kementerian Urusan Konsumen Pemerintah India dalam hasil studinya baru-baru ini juga menunjukkan hanya 20\% konsumen di India yang mengetahui tentang UUPK di negaranya, sementara UUPK di India telah berlaku selama 25 tahun lebih (India mempunyai UUPK tahun 1986). Bahkan hanya $42 \%$ dari konsumen di India yang pernah mendengar tentang hak-hak konsumen. Lebih lanjut ditunjukkan juga bahwa 93\% responden (konsumen di India) yang dirugikan tidak melakukan komplain secara formal dan hanya 3\% responden yang pernah komplain langsung ke pelaku usaha (www.moneylife. in, 2013). Fakta lain menunjukkan bahwa 90\% konsumen di Saudi Arabia tidak mengetahui hak-hak mereka sebagai konsumen. Dalam hal ini ekonom Saudi Arabia, Salem Bajajh menyesalkan kerakusan konsumen Saudi dan ketidakpedulian terhadap hak-haknya. Selanjutnya ia menyatakan:

... consumers should be aware of buying large quantities of unnecessary goods without paying attention to their expiry dates, such as purchasing foodstuffs in bulk. Many such large quantity items are expired at the time of purchase, he said. He said that carelessness and negligence of consumers in choosing the quantity over quality and buying fast-moving consumer goods at low price yet low quality may burden the household budget (Salem Bajajh, 2013: 47).

Kondisi yang tidak jauh berbeda juga ditemukan dalam penelitian penulis tahun 2013 di Daerah Istimewa Yogyakarta (DIY), yang menunjukkan bahwa 59\% responden (konsumen) menyatakan tidak mengetahui adanya Undangundang Nomor 8 Tahun 1999 tentang Perlindungan Konsumen (UUPK). Selanjutnya dari 204 responden yang pernah dirugikan, 117 di antaranya tidak melakukan komplain atau menuntut haknya (Sari Murti W., 2013: 32).

b. Kondisi sosial ekonomi konsumen pada umumnya adalah miskin, kecuali mereka adalah konsumen mobil mewah, rumah, ataupun barang-barang lain 
yang mahal. Daya beli yang "pas-pasan” jelas tidak memungkinkan bagi mereka untuk mendapatkan bantuan hukum (melalui lawyer). Hambatan psikologis ada pada mereka untuk memasuki prosedur hukum formal, selain banyak lawyer yang tidak cukup memahami persoalan-persoalan yang dihadapi si miskin. Pada akhirnya bantuan hukum lebih didominasi oleh kasus-kasus kriminal, perkawinan/perceraian, dan lain-lain, ketimbang kasuskasus konsumen.

c. Mekanisme pemberian ganti rugi yang spesifik juga sekaligus merupakan "kritik" atas dunia peradilan formal yang cenderung tidak efektif. Tegasnya, penyelesaian sengketa konsumen melalui pengadilan tidak cocok, karena sangat formal, lama, berbelit-belit, dan mahal. Gambaran peradilan formal yang demikian itulah yang jelas tidak cocok sebagai media penyelesaian sengketa konsumen. The UK Consumer Council pun menyatakan bahwa: “... in the United Kingdom, the expense of litigation deters the pressing of consumer claims"(John Goldring, 1970: 57).

Fakta di atas menunjukkan bahwa gambaran prosedur peradilan yang formal, mahal dan berbelit-belit, bukan hanya terdapat di negara-negara berkembang saja, tetapi dalam beberapa kasus besar yang menyangkut kerugian dan banyaknya korban, barangkali pengadilan adalah tempat yang sesuai karena aspek "kepastian hukum" seringkali masih dinilai banyak pihak sebagai suatu kelebihan dari dunia litigasi. Selain itu, mekanisme gugatan seperti class action maupun legal standing, hanya dapat dimanfaatkan melalui mekanisme litigasi.

Sehubungan hal tersebut, dibutuhkan instrumen hukum perlindungan konsumen, termasuk di dalamnya mekanisme penyelesaian sengketa konsumen yang cepat, sederhana (tidak formal) dan murah. Apalagi sekarang ini penggantian kerugian yang efektif sudah menjadi salah satu hak dasar konsumen. Dalam konteks ini, harus diakui bahwa keberadaan UUPK belum cukup memadai untuk menjawab kebutuhan akses keadilan konsumen. Hal tersebut dapat dilihat dalam ketentuan Pasal 45 ayat (1) dan (2), Pasal 48 dan Pasal 49 dan seterusnya yang mengatur tentang Badan Penyelesaian Sengketa Konsumen (BPSK). 
Dari ketentuan tersebut, UUPK masih meyakini bahwa sengketa konsumen masih cocok untuk diselesaikan melalui peradilan umum, meskipun juga dibentuk BPSK sebagai alternatif penyelesaian di luar peradilan, tetapi persoalan mendasar UUPK dalam konteks penyelesaian sengketa konsumen sebenarnya berawal dari adanya kontradiksi pengaturan BPSK di dalam UUPK itu sendiri. Di satu sisi Pasal 54 ayat (3) menentukan bahwa: Putusan majelis bersifat final dan mengikat, namun di sisi lain dalam Pasal 56 ayat (2) ditentukan bahwa para pihak dapat mengajukan keberatan kepada Pengadilan Negeri paling lambat 14 (empat belas) hari kerja setelah menerima pemberitahuan putusan BPSK. Bahkan putusan Pengadilan Negeri itupun, berdasarkan Pasal 58 ayat (2) masih mungkin juga diajukan Kasasi ke Mahkamah Agung

Tampak jelas di sini bahwa UUPK masih setengah hati dalam memberikan akses keadilan konsumen melalui jalur non-litigasi yang cepat, sederhana dan murah. Bahkan secara eksplisit cenderung menarik penyelesaian sengketa konsumen dari jalur non-litigasi ke jalur litigasi, yang sudah jelas bersifat formal, membutuhkan waktu yang lama dan biaya yang tidak sedikit (dan tentu saja tidak tepat untuk media penyelesaian sengketa konsumen). Oleh sebab itu dapat dikatakan bahwa UUPK belum dapat menyediakan akses keadilan konsumen melalui pengaturan tentang mekanisme penyelesaian sengketa yang ada.

Berbagai fakta empiris dan yuridis di atas meyakinkan bahwa perlu adanya sebuah mekanisme penyelesaian sengketa yang spesifik, semacam "special tribunal for consumer claims" atau "small claims court", termasuk skema “Consumer Ombudsman". Penguatan kelembagaan BPSK harus dilakukan sehingga dapat menjadi alternatif penyelesaian sengketa konsumen yang efektif. Di sisi lain, keberadaan Ombudsman Republik Indonesia yang diatur dalam Undang-undang Nomor 37 Tahun 2008 tentang Ombudsman Republik Indonesia harus terus dikritisi agar dapat juga berkembang tidak hanya mengawasi pelayanan publik oleh penyelenggara negara dan pemerintahan semata, melainkan juga dapat diperluas bagi tumbuhnya "Consumer Ombudsman" di berbagai sektor usaha/bisnis. Di sisi lain keluarnya Peraturan Mahkamah Agung Nomor 2 Tahun 2015 tentang Tata Cara Penyelesaian Gugatan Sederhana, tampaknya juga masih 
belum sepenuhnya menjawab kebutuhan konsumen karena adanya dua pembatasan, yaitu:

a. Dalam Pasal 3 ayat (1) Peraturan Mahkamah Agung Nomor 2 Tahun 2015 tentang Tata Cara Penyelesaian Gugatan membatasi gugatan yang disebabkan oleh cidera janji dan/atau perbuatan melawan hukum dengan nilai gugatan materil paling banyak Rp. 200.000.000,00 (dua ratus juta rupiah).

b. Dalam Pasal 4 ayat (3) Peraturan Mahkamah Agung Nomor 2 Tahun 2015 tentang Tata Cara Penyelesaian Gugatan ditentukan bahwa penggugat dan tergugat dalam Perma ini hanya terbatas pada mereka yang ada di daerah hukum pengadilan yang sama

Peraturan Mahkamah Agung Nomor 2 Tahun 2015 tentang Tata Cara Penyelesaian Gugatan tampaknya "berjiwa" small claim court, tetapi dengan adanya pembatasan di atas menjadikan Peraturan Mahkamah Agung Nomor 2 Tahun 2015 tentang Tata Cara Penyelesaian Gugatan tidak banyak membawa manfaat bagi konsumen di Indonesia, apalagi dilihat dalam perspektif perdagangan global dan regional dimana lalu lintas barang dan jasa serta transaksi konsumen sudah berlangsung antar wilayah dan bahkan lintas Negara.

Terlihat jelas bahwa perwujudan perniagaan yang berkeadilan membutuhkan peran dan intervensi negara melalui kebijakan dan regulasi yang mampu mendorong terciptanya akses keadilan konsumen. Dalam hal ini Ranjana Das (2009: 21) mengutip pendapat B.M. Brown dalam bukunya Fair Trade: Reform and Realities in the International Trading System menyatakan bahwa negara bertanggung jawab untuk mewujudkan perniagaan berkeadilan. Lebih lanjut dikatakan:

... nation state was considered as the primary agent of development and a democratically run, interventionist state is required to regulate the economy both internationally and domestically; to provide much needed infrastructure, credit, and technology to domestic producers; and to coordinate various sectors within a national economy to ensure diversification and a degree of self-reliance. The state is viewed as having the potential to provide benefits to the fairtraders through the provision of such things as basic social welfare, protection for weak sectors of the domestic economy, and labor and environmental legislation. 
Secara singkat dapat dikatakan bahwa pemerintah dan pengambil kebijakan di bidang hukum harus terus didorong untuk mengembangkan berbagai kebijakan dan regulasi yang mengarah pada penciptaan alternatif kelembagaan perlindungan konsumen sehingga dapat meningkatkan akses keadilan konsumen.

\section{E. Penutup}

1. Akses keadilan konsumen sangat diperlukan dalam mewujudkan perniagaan yang adil karena dalam perspektif perlindungan konsumen, keberadaan akses keadilan konsumen merupakan salah satu unsur atau aspek yang mendasar dalam mewujudkan perniagaan yang berkeadilan. Keberadaan akses keadilan konsumen ini menjadi makin relevan karena masih banyaknya praktik perniagaan yang tidak adil atau tidak jujur dan lemahnya aturan hukum yang memberikan akses keadilan konsumen.

2. Prinsip-prinsip yang perlu dikembangkan dalam peningkatan akses keadilan konsumen mampu mendorong perwujudan perniagaan yang berkeadilan sangat penting dikedepankan dan harus membuka ruang bagi konsumen antara lain:

a. Pemberian bantuan hukum (gratis) pada konsumen yang tidak mampu oleh badan pemerintah;

b. Penyederhanaan prosedur penyelesaian sengketa konsumen guna mewujudkan mekanisme ganti kerugian yang efektif;

c. Penguatan kelembagaan alternatif penyelesaian sengketa konsumen yang mudah diakses dan prosedur yang cepat, sederhana, dan tidak formal serta kekuatan putusannya final dan mengikat seperti Small Claim Court dan Consumer Ombudsman. 


\section{DAFTAR PUSTAKA}

\section{Buku:}

Goldring, John. 1998. Consumer Protection Law. New South Wales: The Federation Press.

Harland, David. 2007. “The United Nations Guidelines for Consumer Protection: Their Impact in the First Decade", dalam Iain Ramsay, Consumer Law in the Global Economy-National and International Dimensions. Aldershot: Darmouth Publishing Company,

Rawls, John. 1971. A Theory of Justice. Cambridge-Massachusetts: Harvard University Press.

\section{Jurnal/Laporan Penelitian/Makalah/Artikel:}

Calliess, Gralf-Peter. 2006. "Online Dispute Resolution, Consumer Redress in a Global Market Place". German Law Journal. Vol. 7. No. 8.

Das, Ranjana. 2009. "Compromising Social Justice in Fairtrade? Case Study of a Fairtrade Organization in India". Working Paper No. 467. Den Haag: Institute of Social Studies.

Djohansjah, J. 2010. “Akses Menuju Keadilan”. Makalah. Pelatihan HAM Bagi Jejaring Komisi Yudisial Bandung diselenggarakan oleh Pusham UII, Komisi Yudisial, dan NCHR. Bandung.

Gibson, Leigh. 1992. "Access to Justice and Consumer Redress within a Single Market". Journal of Consumer Policy. Vol. 15. No. 4.

L'Heureux, Nicole. 1992. "Effective Consumer Acces to Justice: Class Actions". Journal of Consumer Policy. Vol. 15.

Lyttle, Michell. 2009. "Consumer Access to Justice". Article. The Conference on Litigation Costs and Funding. University of Oxford Faculty of Law.

Maggs, Peter B. 1990. "Acces to Justice for the Consumer in the USA". Journal of Consumer Policy. Vol. 13. No. 1.

Ramsay, Iain. 1992. "Consumer Law, Regulatory Capitalism and the, New Learning' in". Article.

Sari Murti W. (et al). 2013. "Pemetaan Masalah Perlindungan Konsumen Sebagai Landasan Pengembangan Kebijakan, Perlindungan Konsumen (Consumer Policy) dan Kebijakan Persaingan Usaha (Competition Policy) di Propinsi DIY. Laporan Penelitian. Yogyakarta: Fakultas Hukum Universitas Atmajaya. 
Takdir Rahmadi. 2006. “Akses Menuju Keadilan”, Sydney Law Review, Vol. 28, No. 9.

UNCTAD. 2001. "Consumer Protection, Competition, Competitiveness and Development". Article. Expert Meeting on Consumer Interests, Competitiveness, Competition and Development. Geneva.

Vel, Jacqueline. 2011. "Policy Research on Access to Justice in Indonesia: A Review of World Bank and UNDP Reports". Law, Social Justice \& Global Development (An Electronic Law Journal).

Widijantoro, J. 2004. "Perlunya Media Penyelesaian Sengketa Konsumen yang Efektif", Makalah, Seminar Kedudukan Prosedur Mediasi di Pengadilan (Perma No. 2 Tahun 2003) dalam Upaya Hukum Penyelesaian Sengketa Konsumen Melalui BPSK, Jakarta.

\section{Internet:}

Bajajh, Salem. "90\% of consumers ignorant of their rights", http://www. arabnews.com/news/452024, diakses tanggal 18 Mei 2013.

Barendrecht, Maurits. (et al). "How to Measure The Price and Quality Access to Justice", http://www.ivogiesen.com/media/1038/access_to_justice_ 2006_ssrn.pdf, diakses pada Tanggal 2 Februari 2016.

CUTS International. "Only 20\% consumers know about consumer protection law" http://www.moneylife.in/article/only-20-consumersowaboutconsumerprotectionlaw, diakses tanggal 13 Maret 2013.

Editor Wikipedia. "Utilitarianisme", http://id.wikipedia.org/wiki/Utilitarianisme, diakses pada 2 Februari 2016.

World Bank. "A Framework for Strengthening Access to Justice in Indonesia", http://www.namati.org/tools/aframeworkforstrengthening access to justicein indonesia2/, diakses pada 2 Februari 2016.

\section{Peraturan Perundang-undangan:}

Republik Indonesia, Undang-undang Nomor 8 Tahun 1999 tentang Perlindungan Konsumen.

Republik Indonesia, Peraturan Mahkamah Agung Nomor 2 Tahun 2015 tentang Tata Cara Penyelesaian Gugatan Sederhana. 


\title{
BIODATA PENULIS
}

\author{
Nama $\quad$ : Abi Jumroh Harahap, SH, M. Kn \\ Pekerjaan : Dosen Fakultas Hukum Universitas Medan Area \\ Jabatan : - \\ Nomor HP $\quad$ : 081376699314 \\ E-mail : abi.jumroh@yahoo.com \\ Alamat Kantor : Jalan Kolam No. 1, Medan Estate, Kota Medan
}

